\title{
Rare Plants and Plant Communities of the Projected "Togul" National Park (Altai Region)
}

\author{
Natalja Elesova, Marina Silanteva* and Liudmila Sokolova \\ Altai State University, Biological Department, Chair of Botany, 656049 Prospect Lenina, 61, Barnaul, \\ Russian Federation
}

\begin{abstract}
The value of the Salair Ridge territory for the creation of the "Togul" National Natural Park is determined primarily by the natural complex of black coniferous forests with the participation of relict plant species of the Miocene-Pliocene coniferous-deciduous forests and a group of early flowering ephemeroid plants, old-aged Pinus sibirica, Picea obovata and linden forests and a variety of tall grasses. Based on the performed geobotanical descriptions, the phytocenotic characteristic of linden forests was compiled. Information is provided on the location of 10 rare and endangered species of plants and fungi found during a survey of the territory of the planned national park.
\end{abstract}

\section{Introduction}

One of the most effective measures for the conservation of natural ecosystems and biological diversity is the creation of national natural parks - specially protected natural areas, which are conservational, environmental education and research institutions. According to the law of Russian Federation 33-Ф3 dated March 14, 1995 "On specially protected natural territories", the following main tasks are assigned to national parks: a) conservation of natural complexes, unique and standard natural sites and objects; b) preservation of historical and cultural objects; c) environmental education of the population; d) creating conditions for regulated tourism and recreation [1-4].

The creation of a protected natural area of federal significance is planned on the Salair Ridge - in three districts of the Altai Region along the border with the Kemerovskaya Oblast (Fig. 1). The goal of creating the "Togul" National Natural Park is to preserve the typical and unique ecosystems of the taiga low-hill terrains of the Salair Ridge. The decision on its creation was made at the meeting of the working group at the Ministry of Natural Resources and Ecology of Altai Region within the framework of the execution of the May decree of the President of the Russian Federation "On the national goals and strategic objectives of the development of the Russian Federation for the period up to 2024". The park area will be about 160240 hectares. It will include the territories of three districts: Zarinsky -24130 hectares $(4.7 \%$ of the district area); Togulsky -77745 hectares $(38.5 \%)$ and Eltsovsky - 58365 hectares $(26.9 \%)$. It is also planned to include into the

\footnotetext{
* Corresponding author: msilan@mail.ru
} 
borders of the national park two existing reserves of regional significance - "Togulsky" and "Eltsovsky" [5].

In 2015-2016 employees of the Gebler Ecological Society and the Chair of Botany of the Altay State University conducted a survey of the vegetation cover of the projected "Togul" national park. The collected herbarium in the amount of 500 herbarium sheets and geobotanical descriptions made it possible to identify the locations of 10 rare and protected plant species (all of them are listed in the Red Book of Altai Region, two of them are listed in the Red Book of the Russian Federation) and characterize linden forests communities.

\section{Botanical and geographical characteristics of the territory}

The territory of the projected "Togul" National Park is located within the western slope and the southern part of the Salair Ridge. In appearance, the Salair Ridge resembles a hilly plain. The highest point is Mount Kivda $(621 \mathrm{~m})$. The whole area is indented by a highly branched river network, gullies and ravines. The forests of Salair favor the formation of precipitations and the aggravation of frontal processes, especially when moving south. Therefore, the territory is characterized by a special climate, which Slyadnev [6] called the "Salair forest climate". The continental climate here is slightly reduced in comparison with the surrounding area: summers are cooler and winters are warmer. The average temperatures in January are $-16 \ldots-17^{\circ} \mathrm{C}$, and in July $+16 \ldots+18^{\circ} \mathrm{C}$. Precipitations ranges from $500 \mathrm{~mm}$ in the north to $800 \mathrm{~mm}$ in the south. In winter, a thick snow cover of more than a meter high is formed [6].

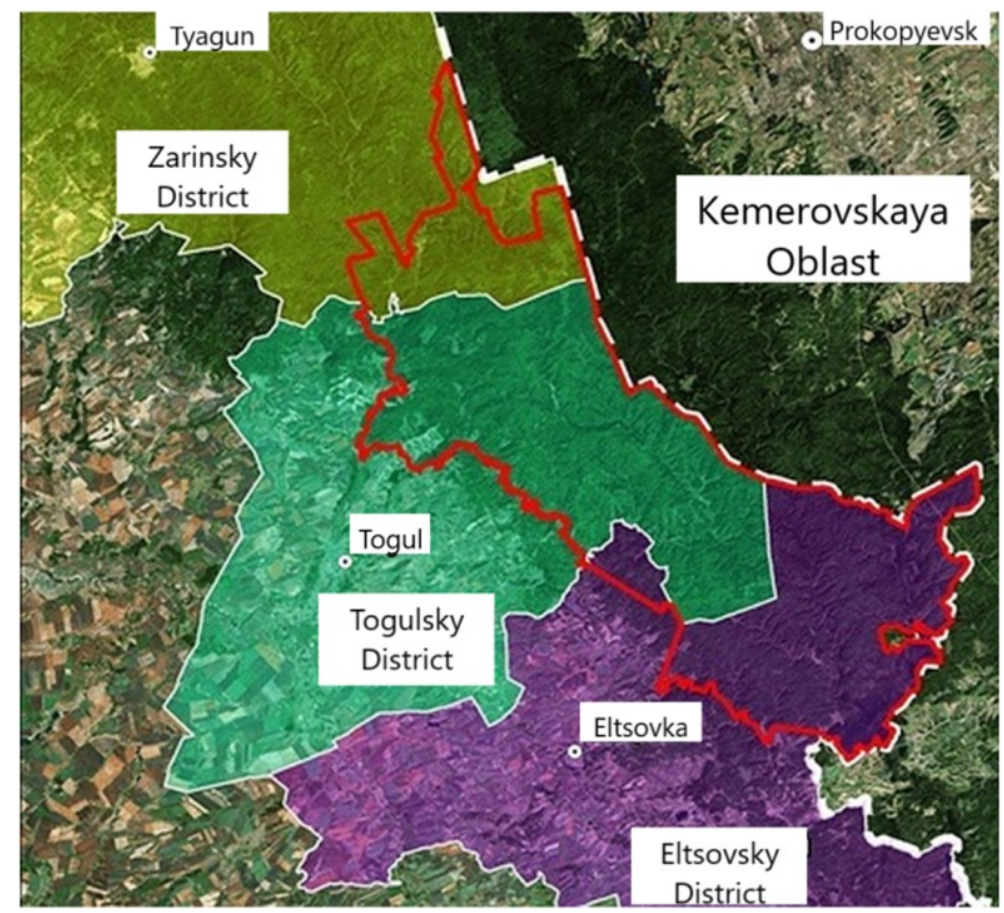

Fig. 1. Projected “Togul” National Park borders (red line)

Under these conditions, soddy coarsely-podzolic and gray forest soils of the black taiga of the Salair ridge are formed. The mother rocks are loess loams. They are characterized by a high humus content reaching in the upper horizon according to P. I. Shavrygin and A. N. 
Rozanov [7] 3.6-6.0\%, and according to L.M. Burlakova, V.A. Rassypnov end L.M. Tatarintsev 7-8 \% [7, 8].

The territory of the projected "Togul" National Park is known primarily for its black coniferous forests, which are the custodians of relict plant species of the Miocene-Pliocene coniferous-deciduous forests: Tilia sibirica L., Brunnera sibirica Stev., Dentaria sibirica (O.E. Schulz) N. Busch, Asperula odorata L., Asarum europaeum L., Sanicula europaea L., Brachypodium sylvaticum (Huds.) P. Beauv. and others [9]. As part of the black taiga, a rare community even on the scale of South Siberia, there will be plots of linden forests. Old-age Pinus sibirica Du Tour and Picea obovata Ledeb. forests preserved in hard-toreach valleys of taiga rivers are also valuable. The age of the oldest trees here reaches several hundred years, and individual Pinus sibirica trees up to 800 years.

The following altitudinal belts are distinguished within the natural park on the Salair ridge: the belt of birch forests and steppificated meadows of the western slope on podzolized chernozems and dark gray forest soils (northern forest-steppe) and the belt of black forests on gray forest and deeply podsolized soils. The black taiga consists of Abies sibirica and in shifts of Populus tremula, in places there are pine, larch and birch. In the valleys of the Chumysh River confluents, one can find aspen-fir forests mixed with spruce [10].

A distinctive feature of Salair's forest phytocenoses is tall grass, which grows on very poor soils. It is developed in more open spaces and burned areas: Aconitum excelsum Rchb., Cacalia hastata L., Euphorbia lutescens Ledeb., Angelica sylvestris L., Festuca gigantea (L.) Vill. end others. In addition, mass spring flowering of early bloomers, including up to 10 types of ephemeroids, is a characteristic of these black forests: Corydalis bracteata (Steph. ex Willd.) Pers., Anemone altaica Fisch. ex C.A. Mey., Erythronium sibiricum (Fisch. et C. A. Mey.) Kryl., Pulmonaria mollis Wulfen ex Hornem, Ranunculus monophyllus Ovcz. end others.

Russian researchers call the black taiga "rain forests of temperate latitudes", as the amount of annual precipitations approaches $1000 \mathrm{~mm}$. A preliminary survey of the territory revealed 43 species of animals and 29 species of plants and fungi listed in the Red Books of various ranks.

\section{Rare plant and fungy species list}

\section{Polypodiaceae Bercht. Et J. Presl.}

Polypodium sibiricum Sipl. Rarely [11].

- Eltsovsky district, Salair ridge, the river Chumysh, outskirts of the river Tatarka. Shaded rocks near the water.

- Eltsovsky district, Salair ridge, Chumysh river, rock Bakharev stone. Moss cliffs on the bank of the Chumysh. N53ำ $18.211^{\prime} \mathrm{E} 86^{\circ} 23.556^{\prime}$.

\section{Aristolochiacaae Juss.}

Asarum europaeum L. Dark coniferous, Abies and linden forests. Usually [11].

- Eltsovsky district, near the village Mostovaya. Aspen-Abies forest. N53 ${ }^{\circ} 45.07^{\prime}$ E86 $76.91^{\prime}$.

\section{Tiliaceae Juss.}

Tilia sibirica L. Dark coniferous forests. Rarely [11].

- Zarinsky district, $1 \mathrm{~km}$ from the river Krutishka. "Togulsky" reserve. MatteucciaAegopodium-Aconitum linden forest. N5342.075' E85 $59.353^{\prime}$.

- Zarinsky district, $3 \mathrm{~km}$ north-east of the village Togulenok. "Togulsky" reserve. HerbsAconitum-Aegopodium linden forest. N53 $41.503^{\prime} \mathrm{E} 85^{\circ} 59.306^{\prime}$.

- Zarinsky district, $2.2 \mathrm{~km}$ to the south-west from the village Togulenok. "Togulsky"

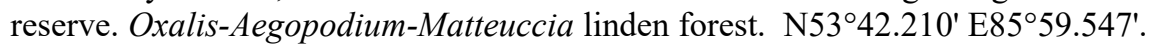


- Zarinsky district, $2.2 \mathrm{~km}$ to the south-west from the village Togulenok. "Togulsky" reserve. Festuca-Aegopodium- Asarum aspen-linden forest. N53 ${ }^{\circ} 42.181^{\prime}$ E86 $00.119^{\prime}$.

\section{Thymelaeaceae Juss.}

Daphne mezereum L. Abies and birch-Abies forests. Rarely [11].

- Eltsovsky district, near the village Mostovaya. Pinus sibirica-Picea-Abies forest. N534․ ${ }^{\circ} 5^{\prime}$ E86 $78.09^{\prime}$.

\section{Boraginaceae Juss.}

Brunnera sibirica Stev. Forest meadows, along rivers and streams. Rarely [11]. River valley Srednij Uksunai, to the confluence of the Kedrovka river. Floodplain forest.

\section{Campanulaceae Juss.}

Campanula trachelium L. Dark coniferous forests. Very rarely [11].

- Eltsovsky district, Salair ridge, the river Chumysh valley. Swamped forest. N53 $3^{\circ} 25.022^{\prime}$ E86 ${ }^{\circ} 48.488^{\prime}$.

- Eltsovsky district, Salair ridge, the river Chumysh valley. Taiga on the slope of the Chumysh valley. N53 ${ }^{\circ} 18.053^{\prime}$ E86 $23.175^{\prime}$.

- Togulsky district, the neighborhood of the village of Malaya Rusyanka. Birch with sporadic Abies forest. N53 $34.281^{\prime}$ E86 $02.154^{\prime}$.

- River valley Srednij Uksunai, to the confluence of the Kedrovka river. Floodplain forest near the swamp.

\section{Liliaceae Juss.}

Erythronium sibiricum (Fisch. et C. A. Mey.) Kryl. Dark coniferous and deciduous forests, forest meadows and forest edges. Usually [11].

\section{Araceae Juss.}

Calla palustris L. Marshes, marshy shores of ponds. Rarely [11].

- Eltsovsky district, the village of Sary-Chumysh, lowland bog. N53²4.54' E86 $75.73^{\prime}$.

- Tolgulsky district, the village Podsopka surroundings, lake Chertovo, swampy shallow water. $\mathrm{N} 53^{\circ} 56.12^{\prime} \mathrm{E} 86^{\circ} 10.23^{\prime}$.

\section{Lobariaceae Chevall.}

Lobaria pulmonaria (L.) Hoffm. Dark coniferous forests. Rarely [11].

- Zarinsky district, $2.2 \mathrm{~km}$ to the south-west from the village Togulenok. "Togulsky" reserve, h $299 \mathrm{~m}$, northeast slope, Oxalis-Aegopodium-Matteuccia linden forest. N53 ${ }^{\circ}$ 42.21, $0^{\prime} \mathrm{E} 85^{\circ} 59.54,7$.

\section{Phallaceae Corda}

Phallus impudicus L. Coniferous, deciduous and mixed forests. Rarely [11].

- Zarinsky district, $3 \mathrm{~km}$ north-east of the village Togulenok, h $317 \mathrm{~m}$. Herbs-AconitumAegopodium linden forest. N53 ${ }^{\circ} 41.50,3^{\prime} \mathrm{E} 85^{\circ} 59.30,6^{\prime}$.

\section{Phytocenotic characteristics of linden forests}

On the basis of the geobotanical descriptions made, a phytocenotic characteristic of the Altai Region linden forests has been compiled.

The tree stand is usually two-layered $22-23 \mathrm{~m}$ high formed by Tilia sibirica, Populus tremula L., Abies sibirica, Betula pendula Roth and Betula pubescens Ehrh. These forests are thick and wet enough; have 70-80\% canopy cover. The average age of Tilia sibirica thees is 60 years old, the average diameter of the linden stems is $23 \mathrm{~cm}$, and the maximum is $38 \mathrm{~cm}$. Abies sibirica and Tilia sibirica are found in the undergrowth. Common projective cover of the shrub layer is 3-10\%, dominant species are Sorbus sibirica Hedl., Caragana frutex (L.) K. Koch, Ribes atropurpureum C.A. Mey. With high constancy there are Padus avium Mill., Lonicera xylosteum L., Sambucus sibirica Nakai. There is no shrub layer sometimes. 
The herbaceous layer has two or three sublayers. Its common projective cover is $65 \%$ (maximum is $85 \%$ ). The first and the second sublayers (tall-grass) dominant species are Crepis sibirica L., Matteuccia strutiopteris (L.) Tod., Aegopodium podagraria L., Aconitum septentrionale Koelle, Festuca altissima All., Urtica dioica L., Pleurospermum uralense Hoffm. Small grass is presented by Asarum europaeum, Oxalis acetosella L., Cerastium pauciflorum Steven ex Ser. and others. There are 56 species of higher vascular plants per $400 \mathrm{~m}^{2}$, including 6 species of herbaceous tertiary relics. The total population area of Tilia sibirica in the Altai Region is about $2 \mathrm{~km}^{2}$.

\section{Conclusion}

Thus, as a result of the study, new information was obtained on the finding of rare and endangered plant species, and the phytocenotic characterization of linden forests was given. The data obtained substantially supplement the idea of the real value of the natural complexes of the Salair Ridge for the creation of the "Togul" National Natural Park.

\section{References}

1. M. Silantyeva, P. Kosachev, A. Kuznetzov, A. Grebennikova, Int. J. of Env. St., 71 (5) (2014)

2. P. Kosachev, E. A. Kryuchkova end P. D., Acta Biologica Sibirica, 3 (4) (2017)

3. S. A. Sheremetova, A. L. Ebel, T. E. Buko, Bull. of Tomsk St. Uni.: Biol., 1 (17) (2012)

4. A.V. Sobisevich, V.A. Snytko, Bull. of Moscow St. Reg. Uni. Series: Nat. Sci., 4 (2018)

5. Newspaper "Altai Pravda" http://ap22.ru/paper/Pervyy-natsional-nyy-park-Togulpoyavitsya-v-Altayskom-krae.html (2019)

6. A. P. Slyadnev, Sketches of climate of Altai region (Barnaul, Alt. publ., 1958)

7. Soils of Altai Region (M., Publ. of USSR Academy of Sciences, 1959)

8. L.M. Burlakova, V.A. Rassypnov, L.M. Tatarintsev, Soils of the Altai Territory (Barnaul, Alt. SKHI, 1988)

9. N. V. Elesova, Probl. of Bot. of South Siberia and Mongolia (2018)

10. V.D. Alexandrova, N.P. Guricheva, L.I. Ivanina, Natural zoning of Altai Krai (M., Science, 1958)

11. Red Book of Altai Region, 1 (2016) 